Portland State University

PDXScholar

1989

\title{
Enhanced realism in the development of my painting
}

Zifan Qian

Portland State University

Follow this and additional works at: https://pdxscholar.library.pdx.edu/open_access_etds

Part of the Art Practice Commons, and the Painting Commons Let us know how access to this document benefits you.

\section{Recommended Citation}

Qian, Zifan, "Enhanced realism in the development of my painting" (1989). Dissertations and Theses. Paper 3919.

https://doi.org/10.15760/etd.5803

This Thesis is brought to you for free and open access. It has been accepted for inclusion in Dissertations and Theses by an authorized administrator of PDXScholar. Please contact us if we can make this document more accessible: pdxscholar@pdx.edu. 
AN ABSTRACT OF THE THESIS OF Zifen Qian for the Master of Fine Arts in Painting presented June 20, 1989.

TITLE: Enhanced Realism in the Development of My Painting APPROVED BY THE MEMBERS OF THE THESIS COMMITTEE:

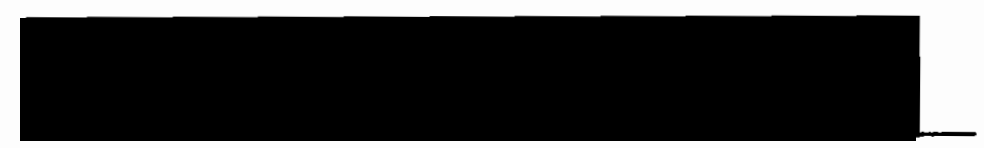

James Hibbard, Chair
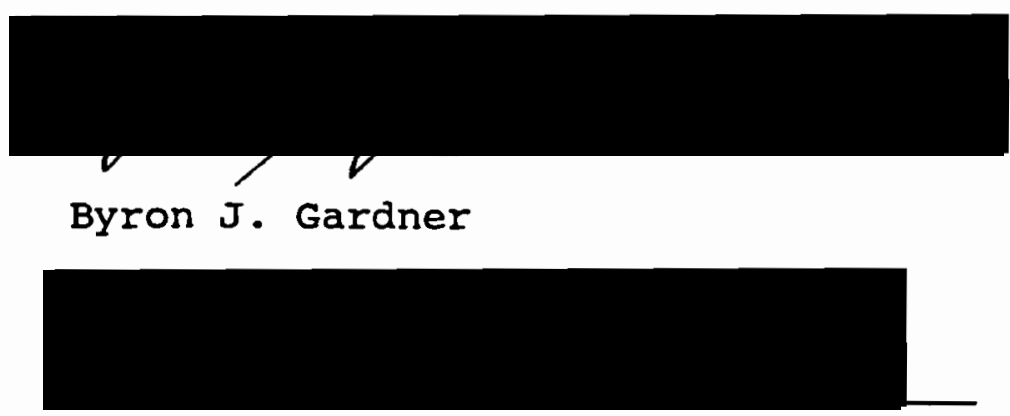

Robert Kasal

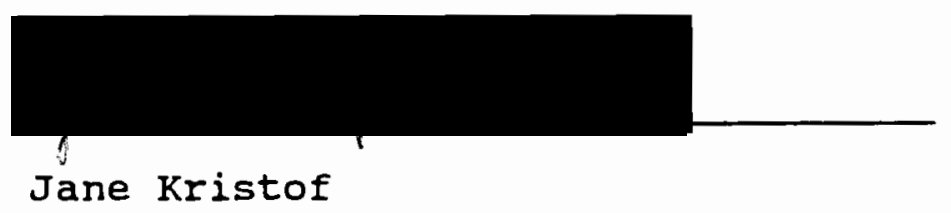

It is a basic truth that the artist must have independent experience and personality in order to create art from life. Combining a traditional realistic style with some elements of abstract composition fits my personality. My paintings represent a pursuit of this idea that is the enhanced realism in the development of my painting. 


\section{ENHANCED REALISM IN THE DEVELOPMENT OF MY PAINTING}

by

ZIFEN QIAN

A thesis submitted in partial fulfillment of the requirements for the degree of

MASTER OF FINE ARTS

in

ART: PAINTING

Portland State University

1989 
TO THE OFFICE OF GRADUATE STUDIES:

The members of the committee approve the thesis report of Zifen Qian presented June 20,1989 .
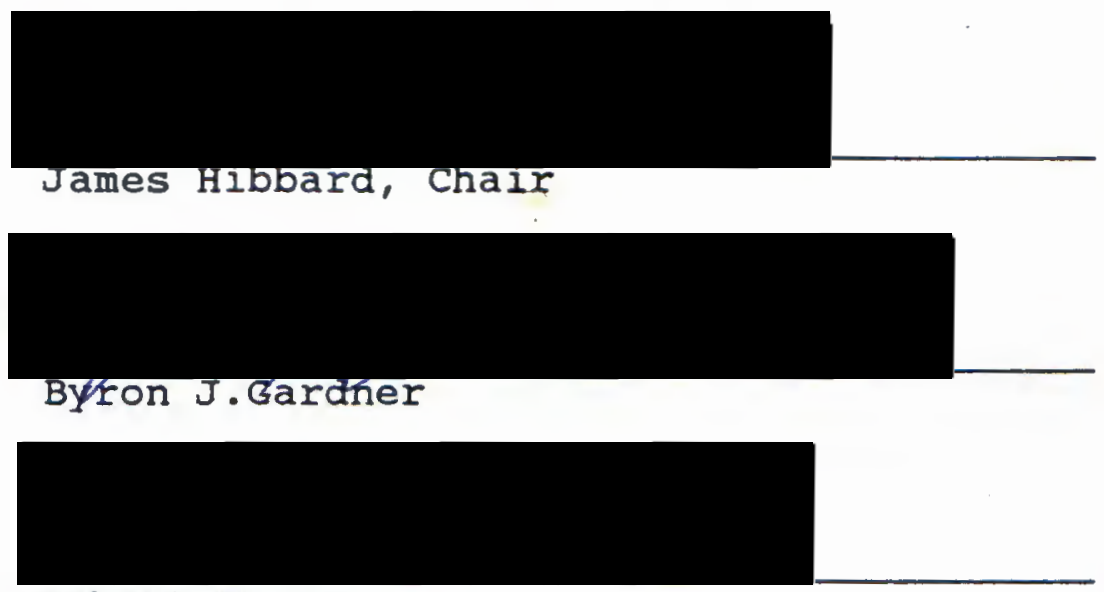

Robert Kasal

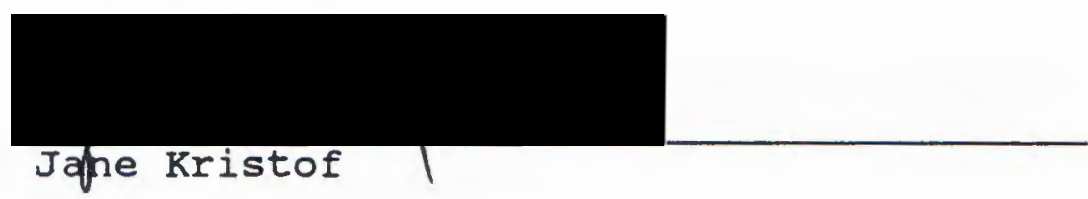

APPROVED:

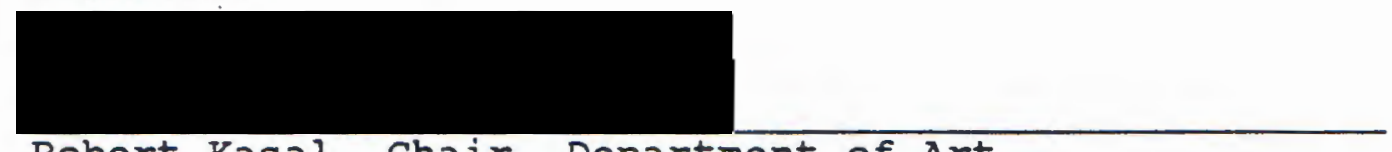

Robert Kasal, Chair, Department of Art

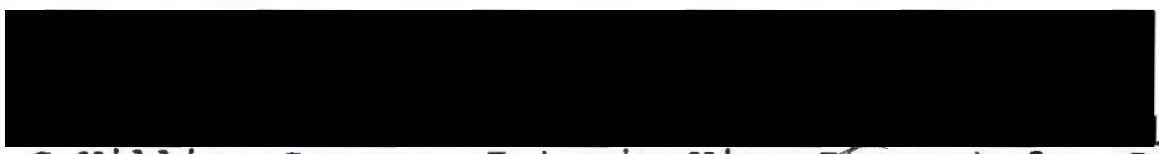

C.William Savery, Interim Vice grovost for Graduate Studies and Research 
TABLE OF CONTENTS

PAGE

LIST OF FIGURES $\ldots \ldots \ldots \ldots \ldots \ldots \ldots \ldots$ iv

BASIC IDEA $\quad \ldots \ldots \ldots \ldots \ldots \ldots \ldots \ldots \ldots \ldots \ldots \ldots$

BACKGROUND OF MY ART TRAINING $\ldots \ldots \ldots \ldots \ldots \ldots . \ldots 2$

DEVELOPMENT OF MY PAINTINGS ............ 7

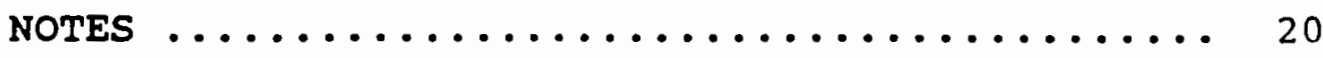

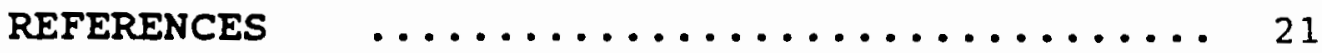

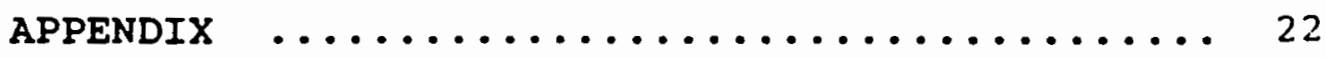




\section{LIST OF FIGURES}

PAGE

1. People in the countzyside... . . . . . 10

2. Facing Nature . . . . . . . . . . . 12

3. Black Nude .. . . . . . . . . . . . 14

4. Girl in the field. . . . . . . . . . 15

5. Girl Before the window . . . . . . . . 16

6. Al Abstract Idea . . . . . . . . . . 17

7. On the Bridge. . . . . . . . . . . 18 
Unhampered by any systematized approach or preconceptions, I have studied the art of the ancients and the art of the moderns. I had no more desire to imitate the one than to copy the other; nor was $I$ any more anxious to attain the empty objective of art for art's sake. No, I simply wanted to extract from the entire body of tradition the rational and independent concepts appropriate to my own personality. To know in order to create, that was my idea. To be able to represent the customs, the ideas, the appearance of my own era according to my own valuation; to be not only a painter but a man as well; in short to create living art; that is my aim.

In my opinion, although the point above came from mid nineteenth-century Europe, it still has meaning today because it is a basic truth that the artist must have independent experience and personality in order to create art from life. While an artist must be faithful to his own observations, believing his own eyes and creating resonant form sincerely, also he or she has to keep in mind that the artist should be part of his time. combining a traditional realistic style with some elements of abstract composition fits my personality. My paintings represent a pursuit of this idea that is the enhanced realism in the development of my painting. 
BACKGROUND OF MY ART TRAINING

My art training in China consisted mostly of realistic depiction based on the nineteenth-century European and Russian traditions as well as Chinese cultural assumptions. This resulted in a style that focused on realistic modeling, a systematic use of color, and taking inspiration from nature and from life which means the content and form of the art work is from real daily human life and natural things. The familiar word "Realism" was first applied to paintings by courbet in 1855; it is opposed to romantic fiction such as Delacroix' work and presents an accurate picture of life as it is lived by ordinary people. The realist, in other words, "is deliberately selective in his material and prefers the commonplace and everyday over the rare aspects of the contemporary scene." 2 This is a basic concept of nineteenth-century Realism. However, elements of realism have a long tradition in oriental as well as Western art history. Seen in its earliest form as anthropomorphic funerary substitute figures such as cows and deer on Shong dynasty (1600 B.C. to 1066 B.C.) bronze 
vessels, elements of realism were fully developed by the time of the Han dynasty (206 B.C. to A.D. 8). Besides bronze, they were also fashioned from a variety of other materials such as terra cotta. So remarkably life-like are those figures that it would seem as if chinese craftsmen had always had the gift of transforming flesh into clay. For two thousand years, the chinese realistic way was cultivated and refined into a style that bears little relationship to the Han version, though it provides authentic sources for twentieth-century forms. In the early years of the twentieth century of China, Shanghai became the center for foreign ideas. since some artists of that time felt that traditional Chinese art was bankrupt, they argued that borrowed and adopted aspects of Western art would revitalize the lifeless Chinese formulas and produce a new kind of Chinese art. In the twentieth-century, western traditional painting skills that were associated with science or technology--drafting, mapmaking, and illustrating--became part of the educational plan within the modern school curriculum. The first arts and crafts department was established in 1906 at the Nanjing Normal High school, and a test of artistic achievement was included in the new official examinations. The new method of Western art education introduced drawing with pencils and charcoal, painting in oil on canvas, the use 
of watercolor and gouache on nonabsorbent paper instead of ink and color washes on absorbent paper or silk. other innovations included drawing from life (using draped and nude models) and from plaster casts and painting from arranged still lifes and landscapes. The new art movement was led by different apostles in different cities, and evolved into different styles. In Nanjing, classicism almost copied European eighteenth and nineteenth- century academic styles. In Hangshou, self-expression based on Post-Impressionist art techniques was employed. In Shanghai and Beijing, other progressive painters explored many alternatives such as realism which was based on nineteenth- century European and Russian traditions. From the time the People's Republic of China was established to the death of Mao Zedong in 1976, Chinese socialist Realist art was influenced by the Soviet Union. The art of the soviet Union combines the Russian realistic tradition with the revolutionary idea. So the Chinese socialist Realist models are brilliantly colored, grouped compositions of larger-than-life, red-faced heroes of war and peace. Otherwise, the Chinese version of Romantic Realism was similar to Socialist Realism of the Soviet Union. The Chinese painter, Xu Beihong's (1895-1953) academic vision of Romantic Realism was based on nineteenth-century French traditions. $\mathrm{Xu}$ studied art in France and brought 
it to China and influenced contemporary art in China.

Chinese art in the post-Mao period is at a crossroad. As the work evolves, it reflects the major changes taking place in china. In the academies of art realism still dominates the training. However, influences from European realistic traditions and contemporary Western art are evident. The faculty at the shanghai Normal University Art Department trains students to appreciate the European realistic traditions. During my four years there, I followed the standard program for art students which included drawing, anatomy, color schemes, and psychology in the first year. In the second year, additional classes included oil painting, watercolor, and art history (both Eastern and Western traditions). The third year focused upon composition, incorporating the figure, still life, and landscape. The fourth year was devoted to my thesis work in painting, examples of which I brought to America and exhibited in Portland in 1987. Since China has welcomed Western influence in recent years, our generation has been exposed to many styles of modern Western art. Artists and scholars suddenly had access to a range of foreign books and magazines; much of this material came from the United states. In late 1978 and early 1979, for the first time, the government tolerated Chinese artistic expression in modern styles, beginning with Impressionism and on 
through the other "isms." The government planned cultural exchanges that included exhibitions of foreign art and programs for artists from the West and Japan to study and teach in China and for chinese artists to study abroad. I became interested in several aspects of this Western import while I still was in China and experimented with a complete reversal of Chinese realistic traditions and color collages in 1983-1984. About 1983 or 1984 , I did some lyric abstract paintings on Chinese paper and in Chinese-colored ink and some paintings influenced by German Expressionism. When Picasso's paintings were exhibited in shanghai in 1985, I and other Shanghai painters made some cubist paintings. We even combined Chinese "New Year's Painting", a sort of folk poster painting for celebrating the Chinese New Year, with Western Cubist painting with an interesting result. These experiments left me dissatisfied. This is why I came to the United states where the various traditions intermingle and coexist. 


\section{DEVELOPMENT OF MY PAINTINGS}

Because of my natural inclinations and the influences I found in school, I have always been drawn to realistic styles represented in Western art by painters such as Vermeer, Courbet, and Eakens etc.. At the same time, I wish to absorb elements from different styles. While studying at Portland State University, I have developed and altered my thinking and working methods for my realistic style. I have recieved support and critical advice from several professors in the Art Department. Professor Gardner told me that I should emphasize the composition of paintings and consider every corner in a complete work. Also, professor Hibbard suggested that I might combine some elements of Surrealism with my realistic style. While in china, I often concentrated on a single focus or a central subject with everything in the picture subordinated to that. About 1986 I worked surrealistically in attempting a close copy of Salvador Dali's style. But I found I had not absorbed the elements of surrealism when I did my familiar painting style. However, from Gardner and Hibbard I learned that the surface design has to be 
considered as fundamental to the integrity of composition whatever the style. Also, the courses of Professor Cheshire taught me an expressionistic style in watercolor. John Marin's works and Cheshire's brush stroke technique in watercolor were consulted often by me. I took courses from Professors Katz and Muller in which I did some abstract paintings. During the two years of my graduate studies I took courses in art history from the Renaissance to the present. I visited museums and galleries in Portland, Seattle, and San Francisco and observed other styles and treatments of painted form. In order to develop and establish my style, I tried to keep my vision independent while at the same time absorbing elements from works that interested me. In the midst of the various traditions I began to think more deeply about the value of art and began to do some new works.

The new works I did from 1987 to 1989 are the continuation of the painting style I did in China. My basic concern for representational form had remained strong. I developed as an artist under the influence of realistic art, and although I have evolved in differnt directions, I see my early training in China as having defined my artistic character. Through my studies at Portland State University, I have been able to examine the realism I employed in China, and I decided to make several changes. 
The new works featured brighter colors with stronger contrast of hue and new forms of composition. "People the Countryside" (Figure 1) is an example. The painting is the bigest of my works; the size is $51.5 \times 104.5$ inches in this painting. I stressed color in a way I have seldom done before, and did not much care about narrative traditional chinese contents of the painting. I arranged large color divisions in horizontal bands and did not imitate natural color anymore. The shirts and baby-cap of the figures from three diverse red shapes with the yellow-green shapes in the grass combine color harmony and contrast. This kind of color arrangement is important to me for its beauty independent of any religious, political or poetic meaning. This indicates an important change from the way I was working under the influence of my chinese art professors, they insisted that the narrative meaning (in their minds a painting definition of content) was the fundamental point from which to begin a painting. Also, I considered new forms of composition in the "People in the Countryside." The picture by using some elements such as single-point perspective and symmetrical balance strengthen the feeling of formality and unity.

I have come to realize how important underlying abstract design is in the organization of any painting. My recent compositions manifest this. In these works I 


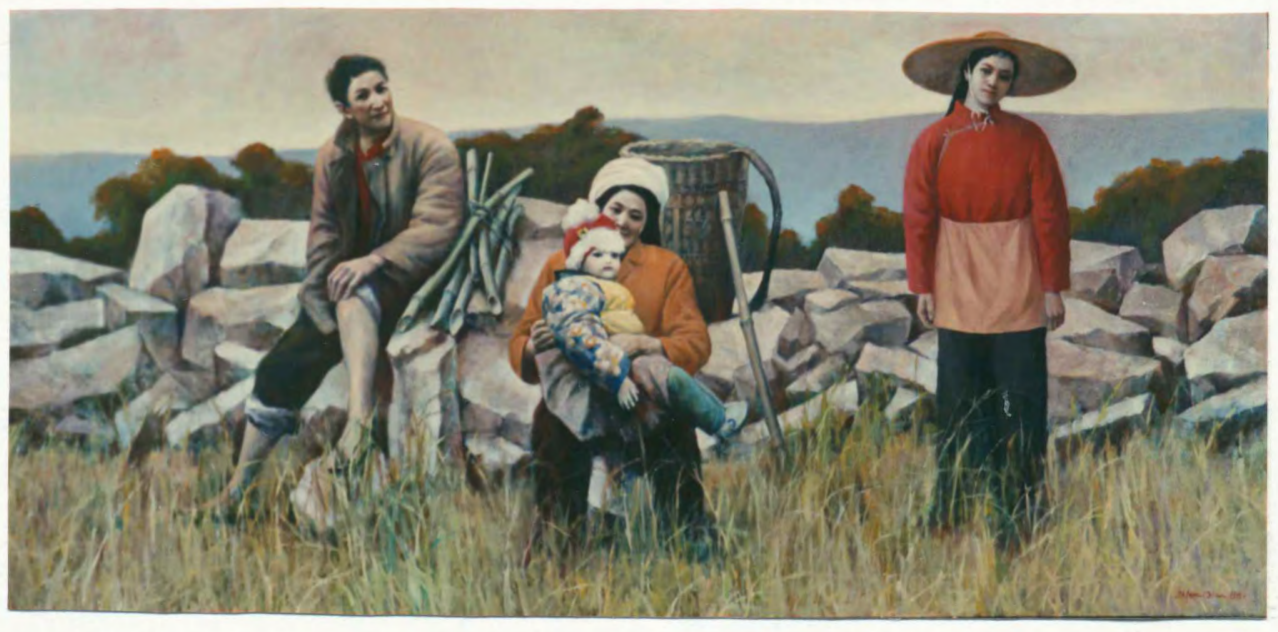

Figure 1. People in the Countryside 
try to become more personal and at the same time express my interest in western composition. In some of my new works I concentrate on formal compositional factors and use shadows to dramatize my idea. "Facing Nature" (Figure 2) is an example.

The shadow forms in this painting are stressed. The painting has large shapes from the shadows, window, sky with the landscape and the figure which is a person seen from behind, sitting on the chair facing out a window looking towards the natural landscape. These shapes (the shadows) are stressed to a degree that is new to me (in China, called the ornamental feeling). The shadow forms give a perspective direction which to concertrates on the figure in the center of the painting. The back in this composition continues the wall of the room, an enclosure, which seperates the viewer from nature while the picture subject is experiencing nature. I combine the hard architectural lines from the man-made world with the softer lines of nature. A sense of loneliness and isolation is reduced by the invitation of nature. This construction is a romanticized setting although it deals with ordinary subjects. It is a glimpse of real life. This realisticc style does not imitate the nature but enhances it.

The separation of my paintings into foreground, middle-ground, and background has always been important 


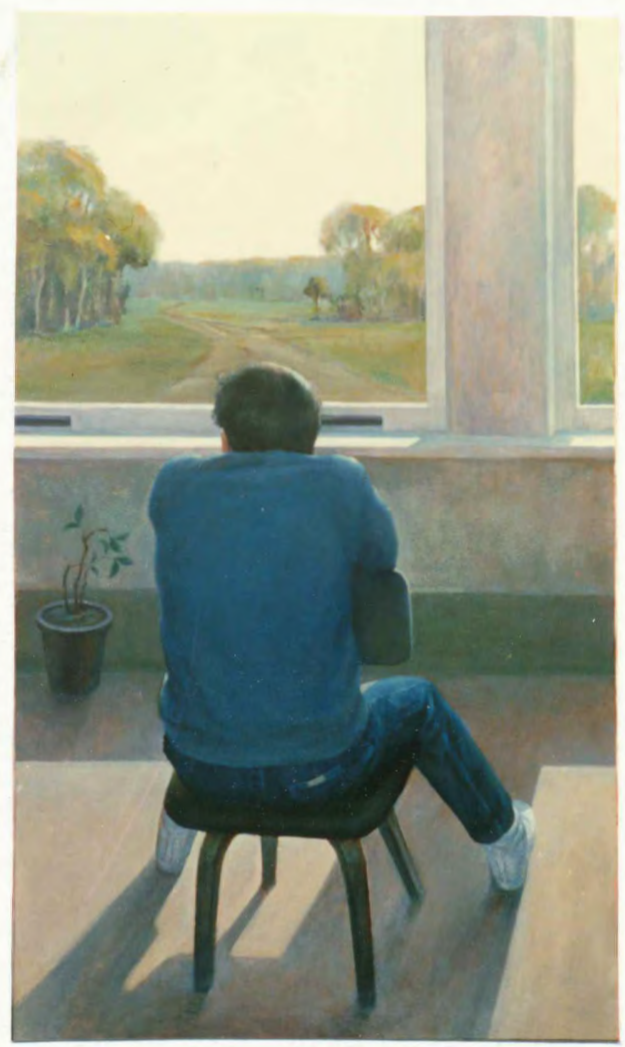

Figure 2. Facing Nature 
to me as it has been very often to traditional Western artists. After discussing this matter with professor Gardner and Hibbard, I realized that the foreground activity (the white lamp and colorful drape in the painting "Black Nude", Figure 3 ) is like the pictorial device so often used by Vermeer. Compositional serenity of Wyeth interests me and I employed this simplicity in my paintings such as "Girl In The Field" (Figure 4), "Girl Before The Window" (Figure 5). Also, these paintings ware influenced by sargent, the oil technique is realistic and vigorous as his always was. "An Abstract Idea" (Figure 6), makes references to contemporary furnishings and their unexpressive shapes, an interest I share with David Hockney. However, there are my personality and new idea in those works in spite of enhancing the achevement from them.

In my recent paintings I have compressed my ideas about pictorial form and the poetic aspect of the subject by eliminating useless detail. They have more power than the paintings I did in China. For an example, in the painting "On the Bridge" (Figure. 7 ). I simplified my composition and compressed local colors. The sky is only one big silver shape, the bridge is nearly a simple grand band between white bands, and the color of the girl standing on the bridge is simplified also. The small orange color in the figure dress is surrounded by 


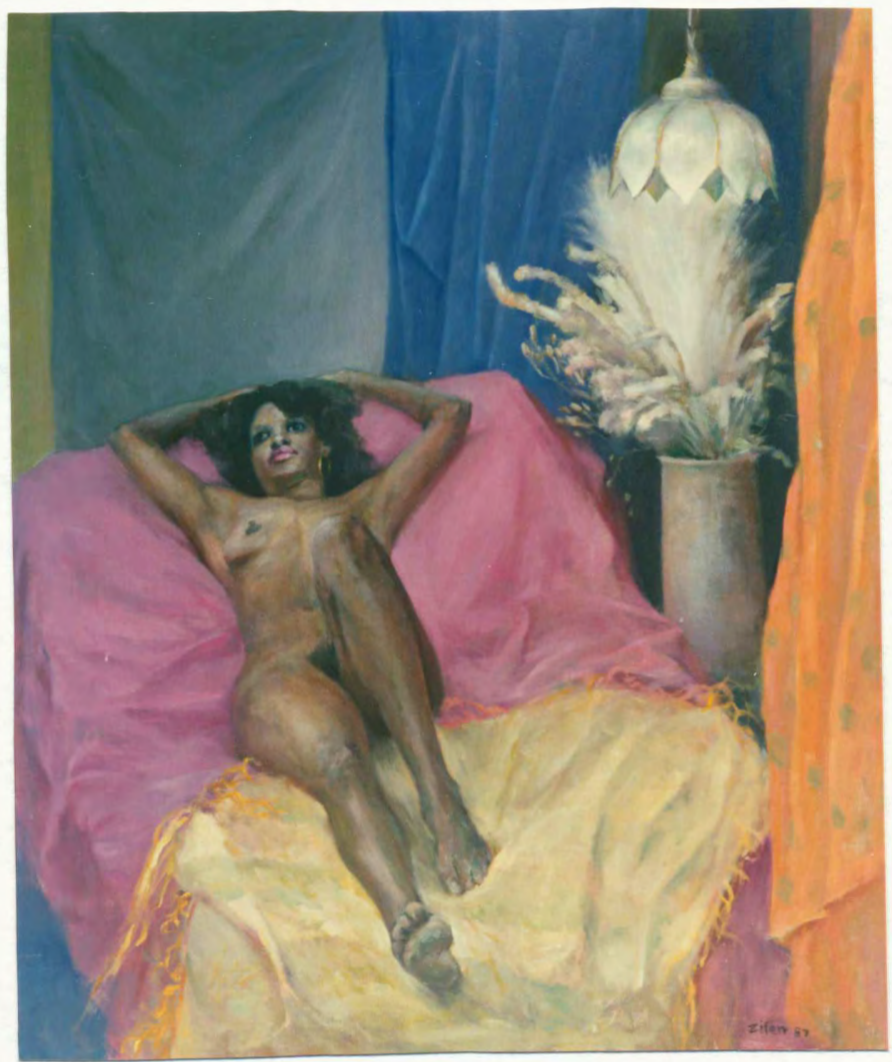

Figure 3. Black Nude 


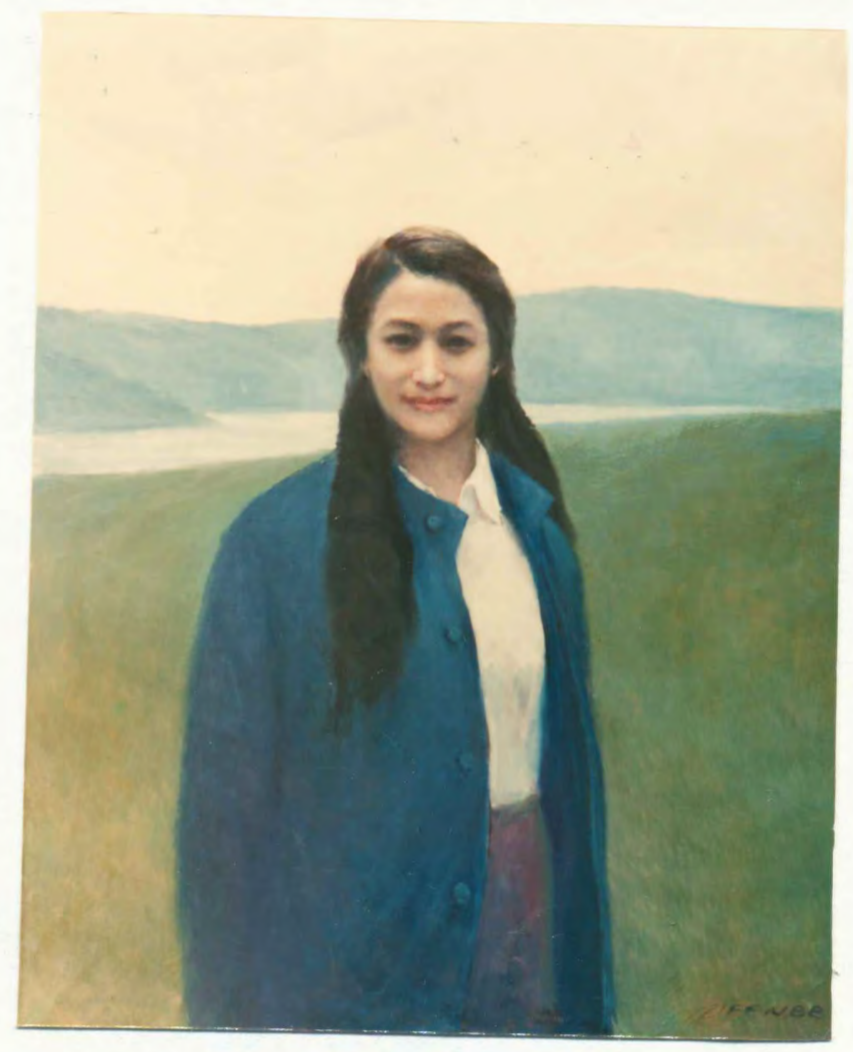

Figure 4. Girl in the Field 


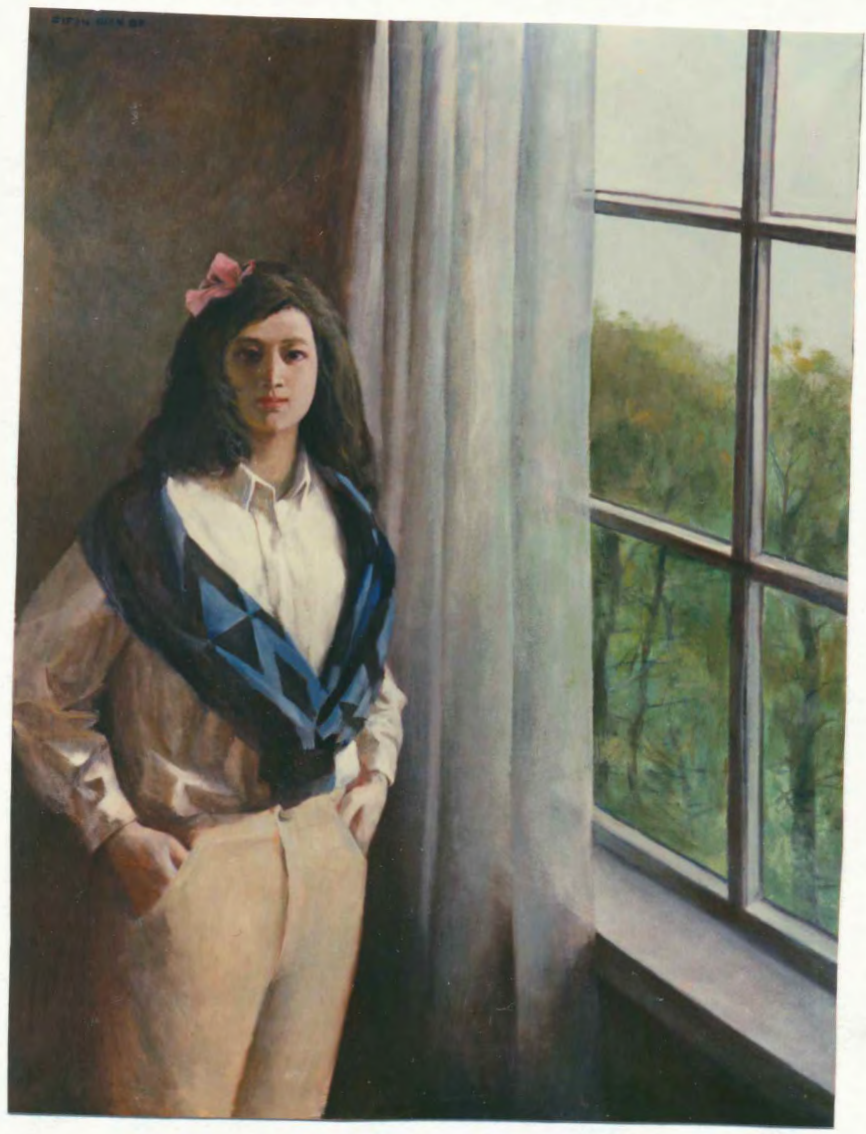

Figure 5. Girl Before the window 


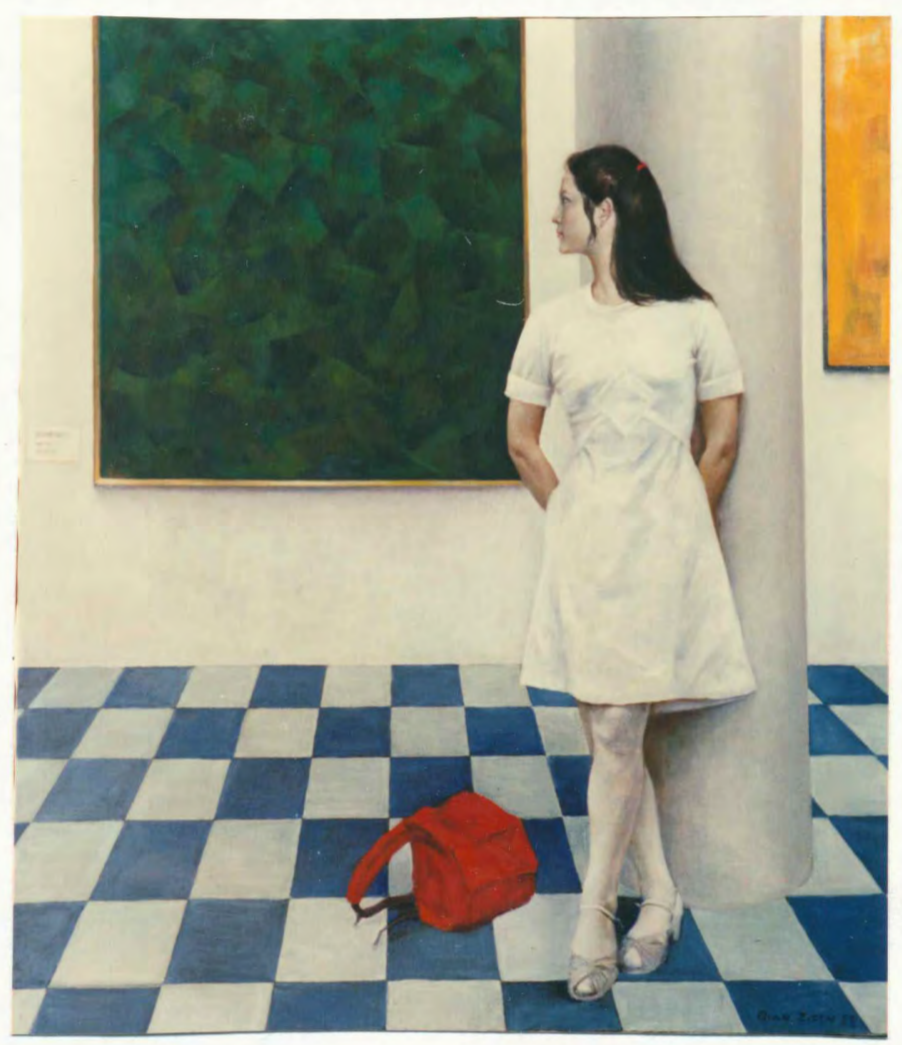

Figure 6. An Abstract Idea 


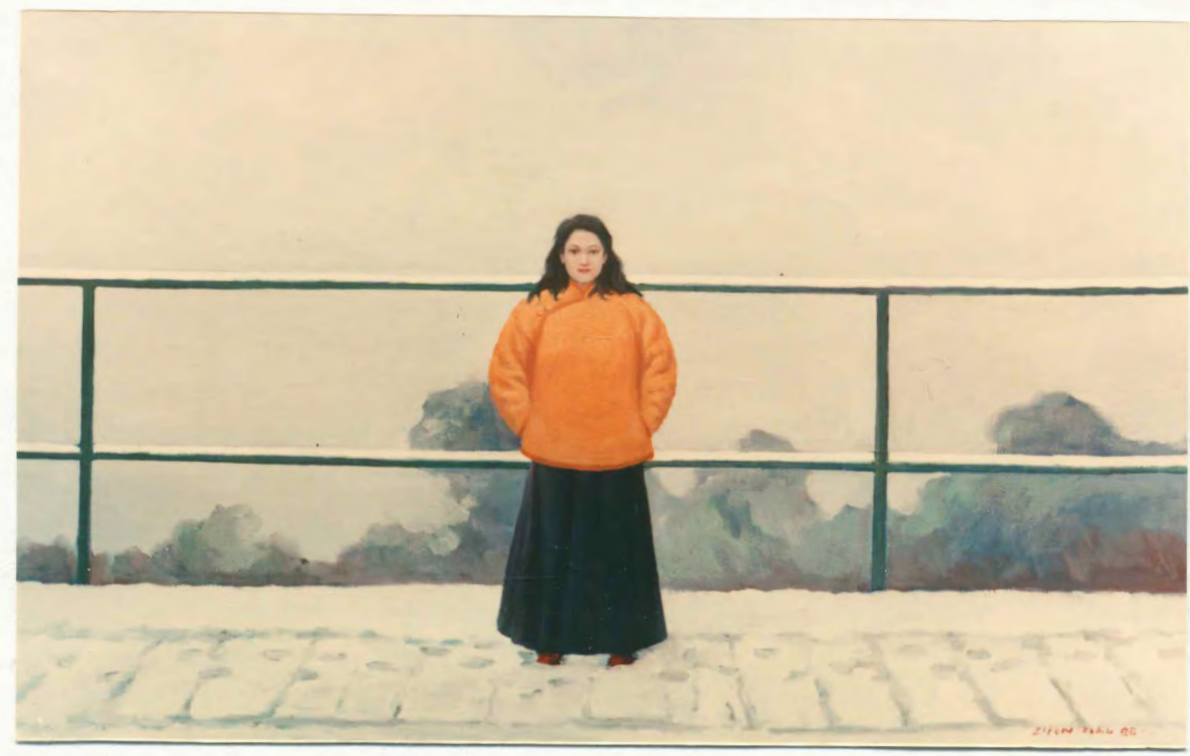

Figure 7. On the Bridge 
complementary silver color creating a quiet poetic aspect typical of a snowfall. The concise and abstract composition of this painting is influenced by some abstract works of Piet Mondrian and Theo Van Doesburg. These abstract influences combine with specific detail create an enhanced mood that is identifiable and nostalgic.

In the modern age ---

all of the new expressions and movements represent a fundamental break with past traditions, and the result has been an immense destruction of received art forms. While this has meant a downgrading of classicism, on the positive side it has also invited an almost greedy acquisition of new forms from all over the globe, from non-Western, oriental and primitive cultures, and from folk art, the art of children and the insane, and other aspects of art. The outcome of these vast changes has not merely been a spirit of assimilative eclecticism, but instead, the birth of a new tradition more subjective in spirit. (3)

My new work is the result of absorbing the ideas from this new tradition and also taking inspiration directly from real life as well as borrowing aspects attractive to me from past traditions. My work represents an attempt at unifying these two separate entities.

The difficulty of describing works of art with words is doubly apparent to me as my native language, Chinese. Perhaps the partial Chinese translation of this paper will indicate to the reader how different my response to the life that surrounds me is from most western artists. Art, like magic, can not be described but must be directly experienced. 
NOTES

(1) Gerstle Mack, Gustave Courbet (New York: Alfred A. Knopf, Inc., 1951) 136-7.

(2) M. H. Abrams. A Glossary of Literary Terms, eds. Dan S. Norton and Peter Rushton (1941) 11.

(3) Sam Hunter and John Jacobus. Modern Art (New Jersey: Prentice-Hall, Inc. Englewood Cliffs, New York: Harry N. Abrams, Inc. 1985) 13. 


\section{REFERENCES}

Abrams, M. H. A Glossary of Literary Terms. Eds. Dan S.Norton and Peter Rushton, 1941. 11.

Beming, Huang. History of Chinese Painting. Shanghai: Shanghai People's Arts Publications, Inc., 1983.

Levey, Michael. A Concise History of Painting. Singapore: F.E.P. International Pte Ltd. Reprinted 1984 .

Sam Hunter and John Jacobus. Modern Art. New Jersey: Prentice-Hall, Inc., Englewood Cliffs. New York: Harry N. Abrams, Inc. 1985. 
APPENDIX

CONCISE TRANSLATION IN CHINESE 
地察家留要第 鸽相应基富父 造想该等客简

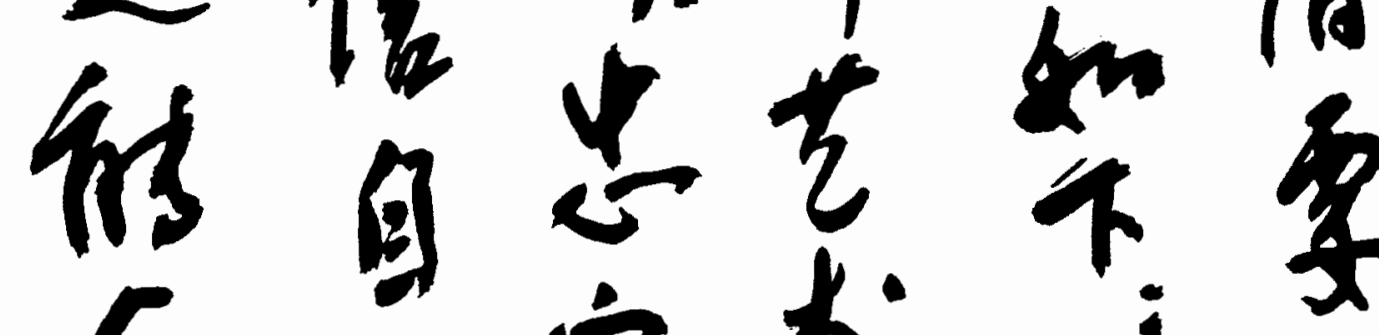

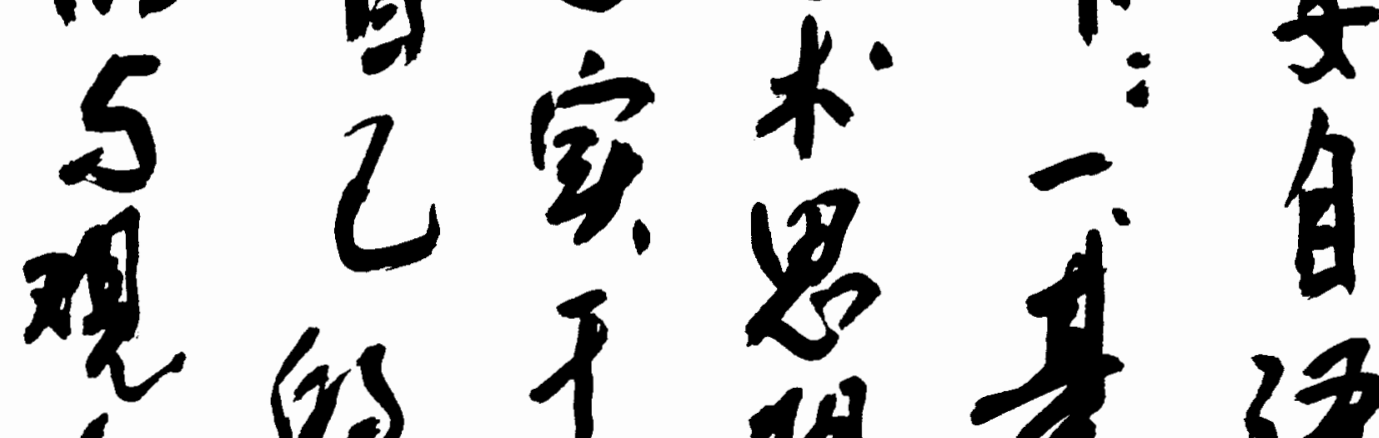
公的手鼻量垏 韵照的是界金

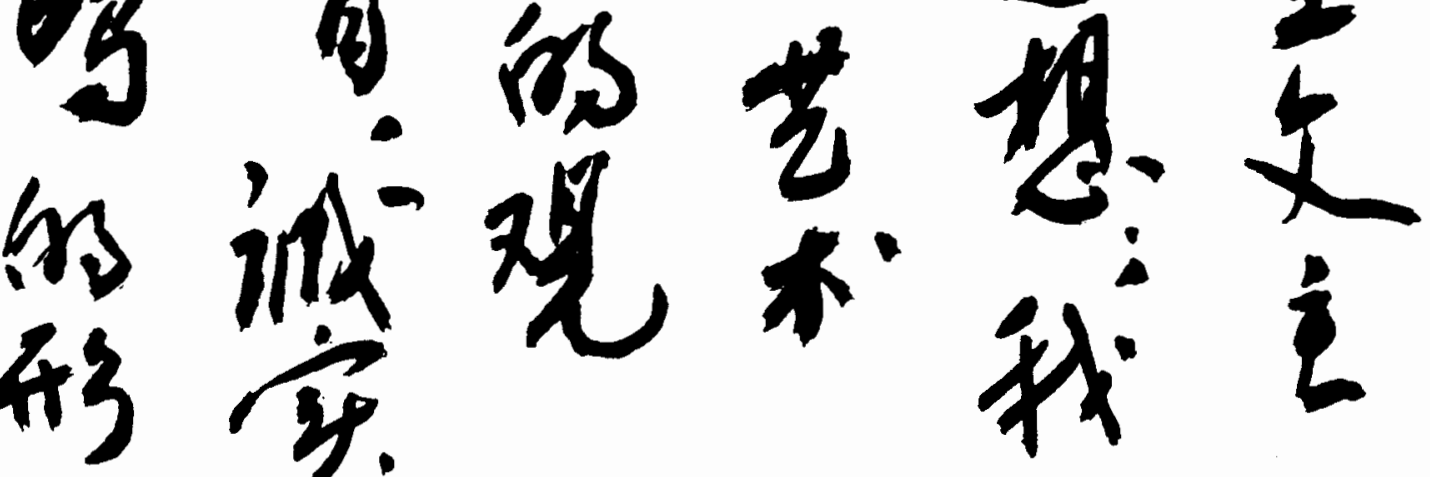


二作此合倍式。 我品具指和结 的得基我现合

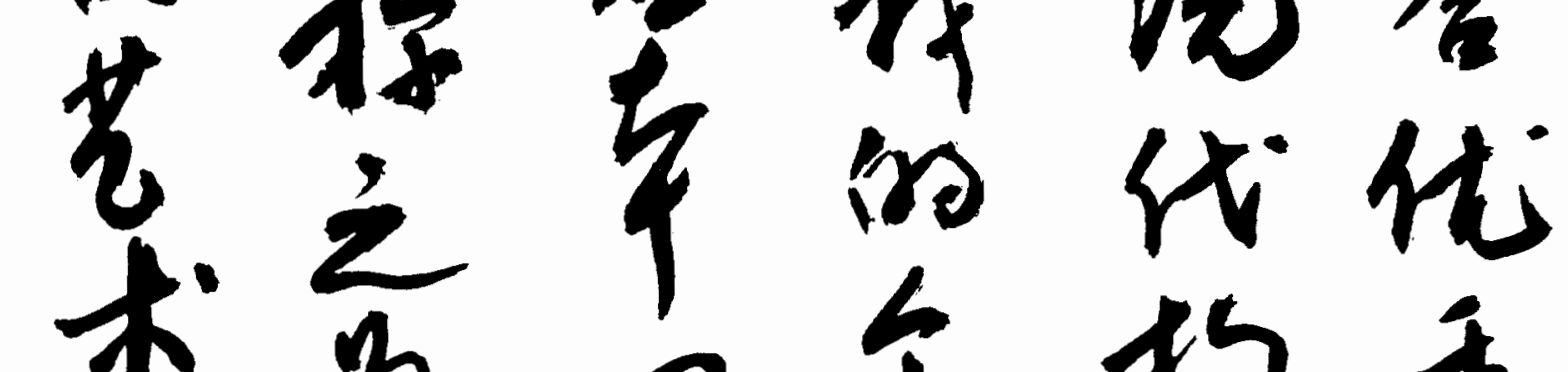
和要思物秀

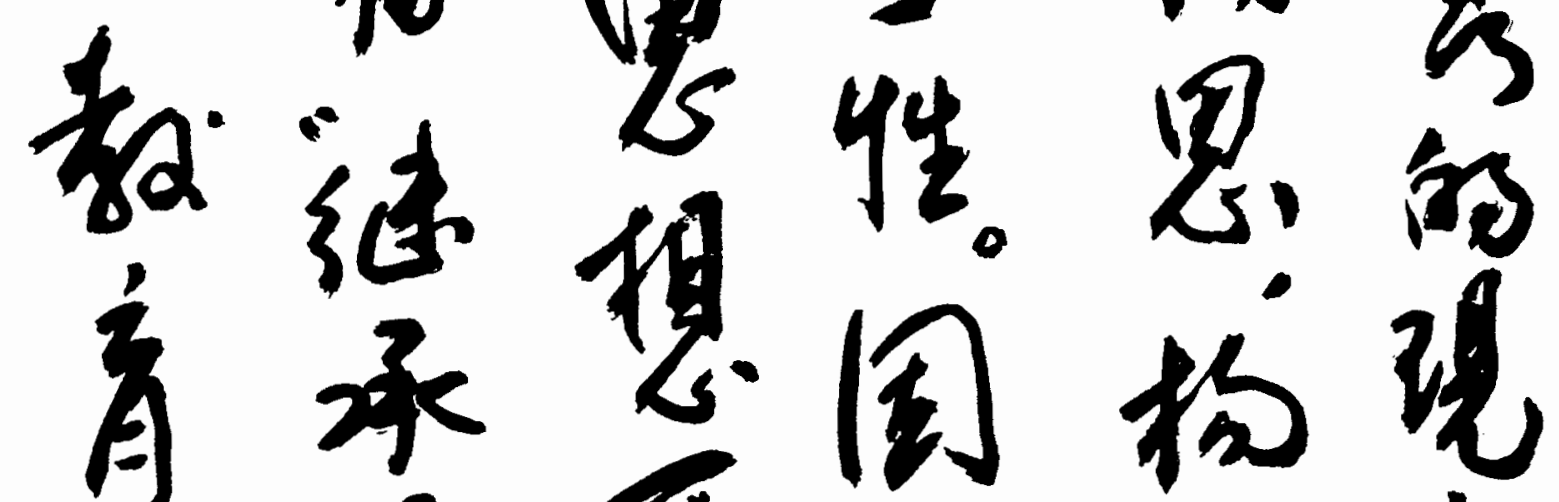
育录想国物说

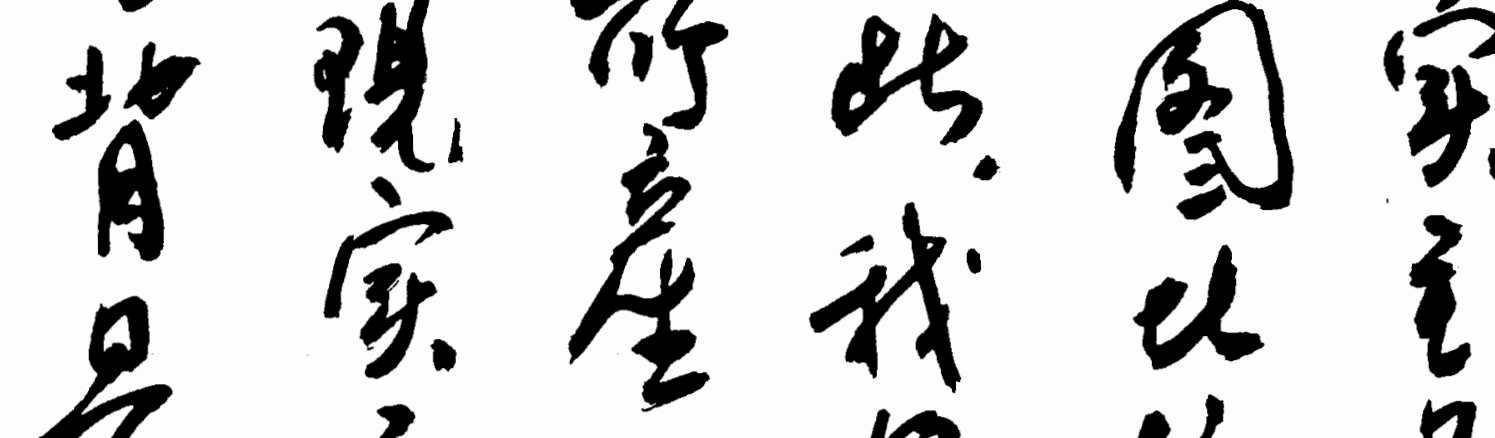

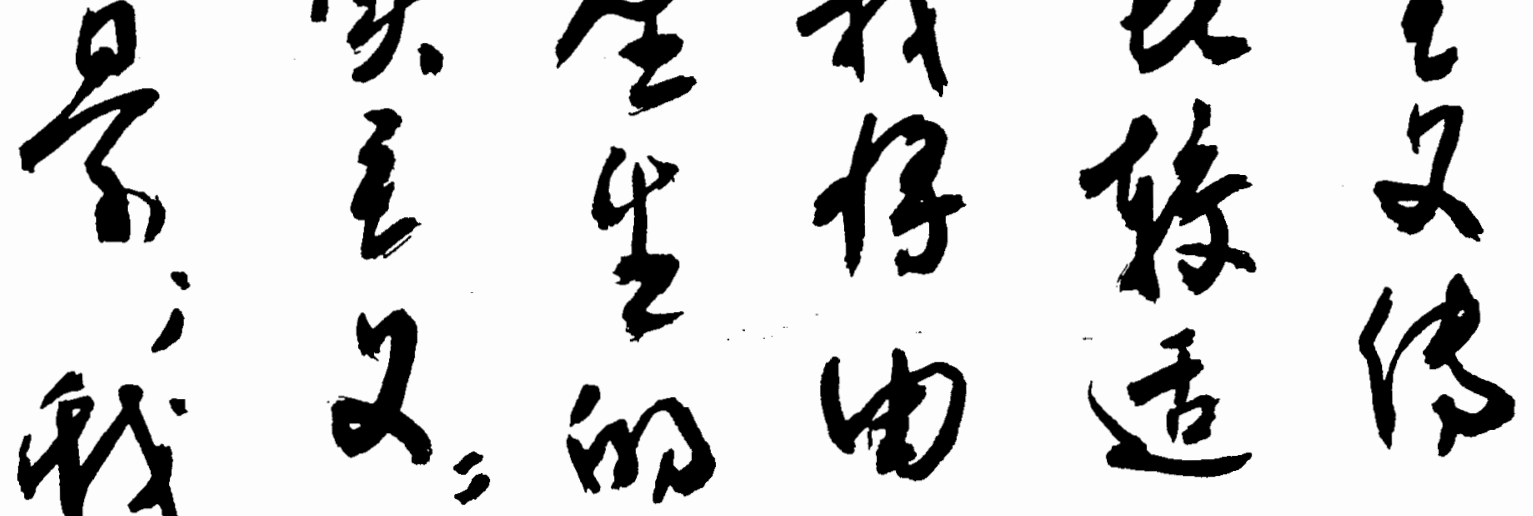


现国间斯自要

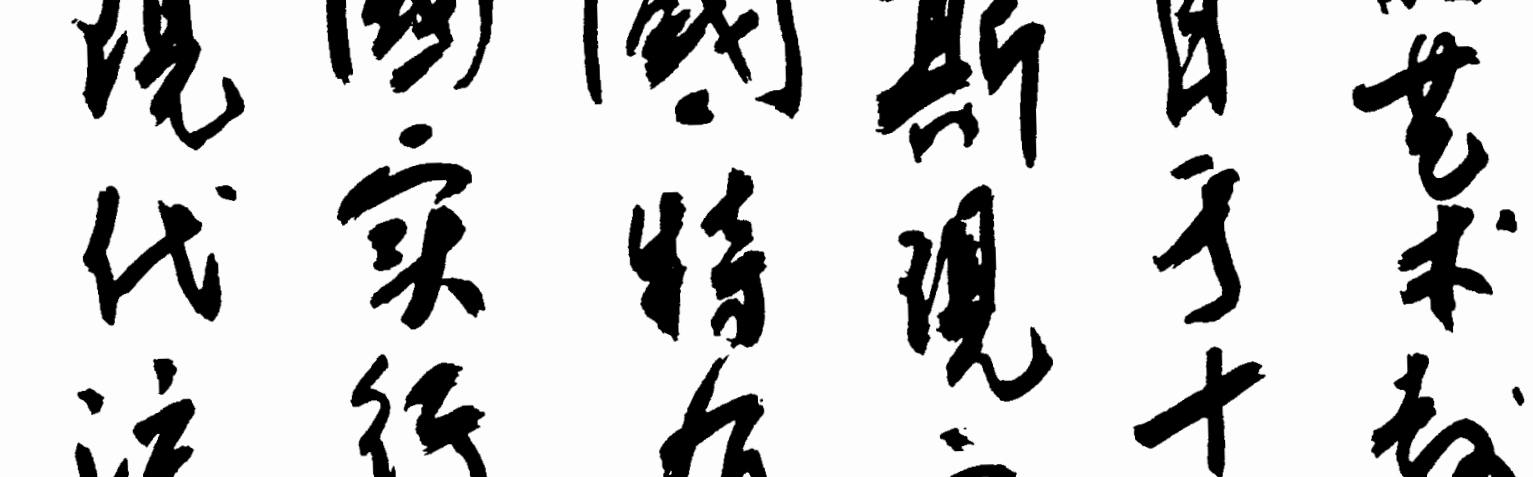

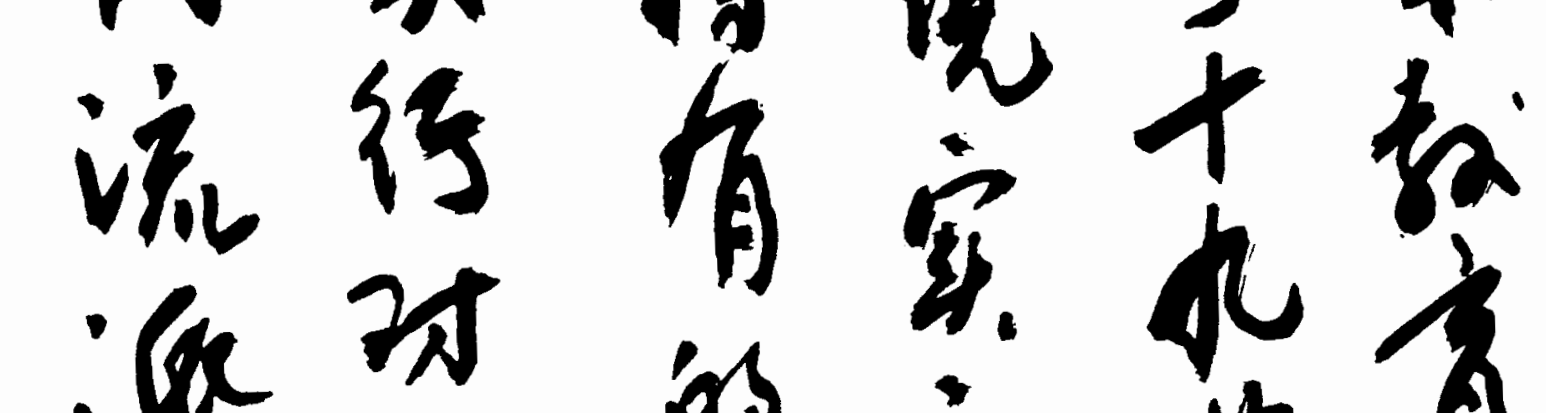

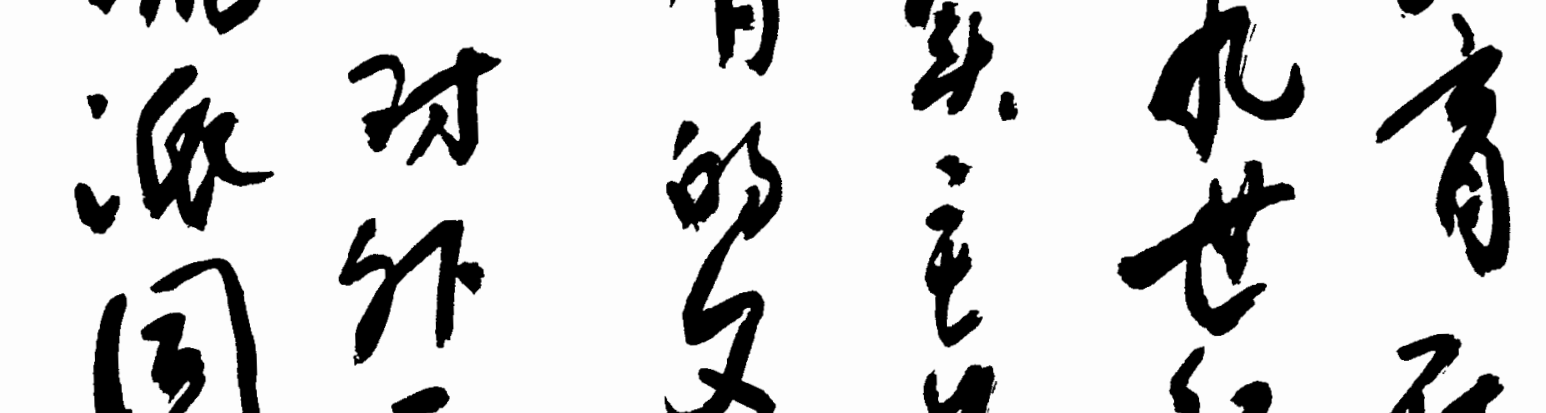

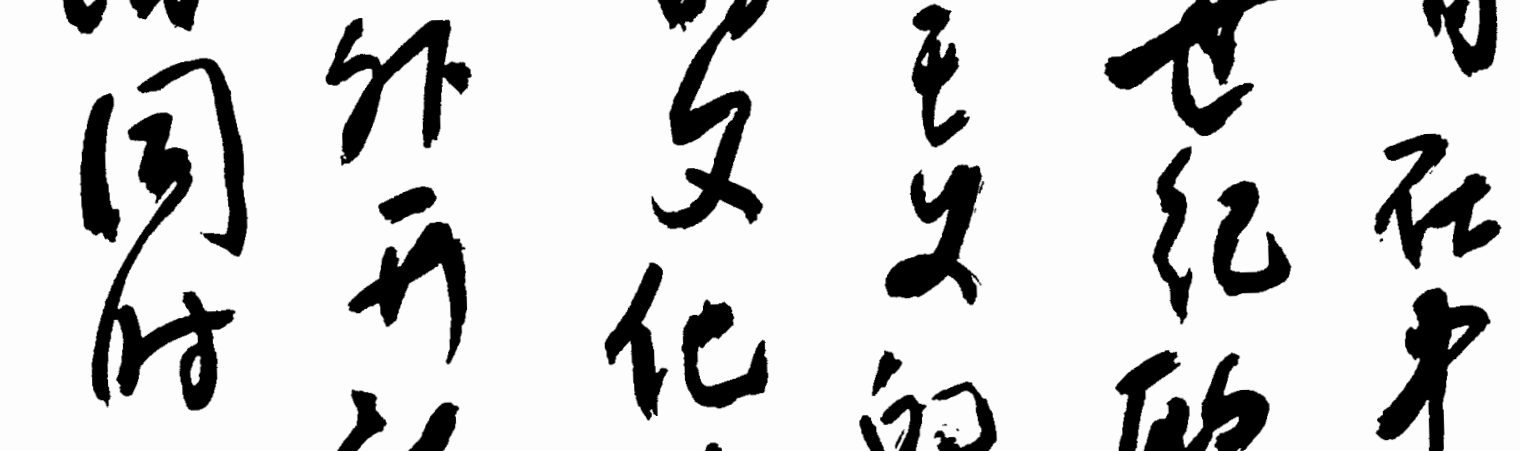
放留得欧 成策是统等 我名自驾线要

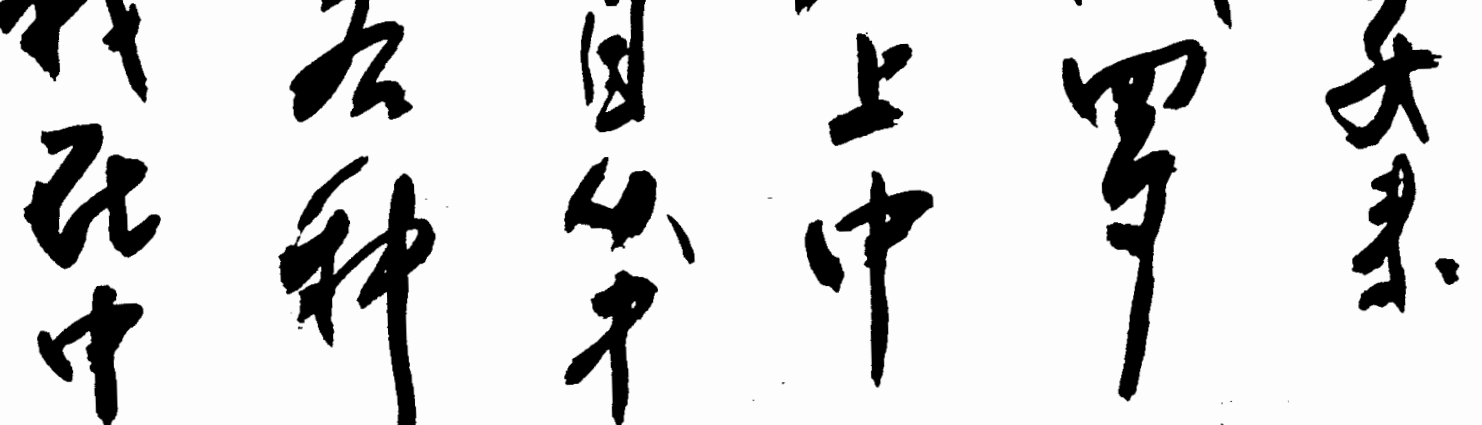


创在育造莩图

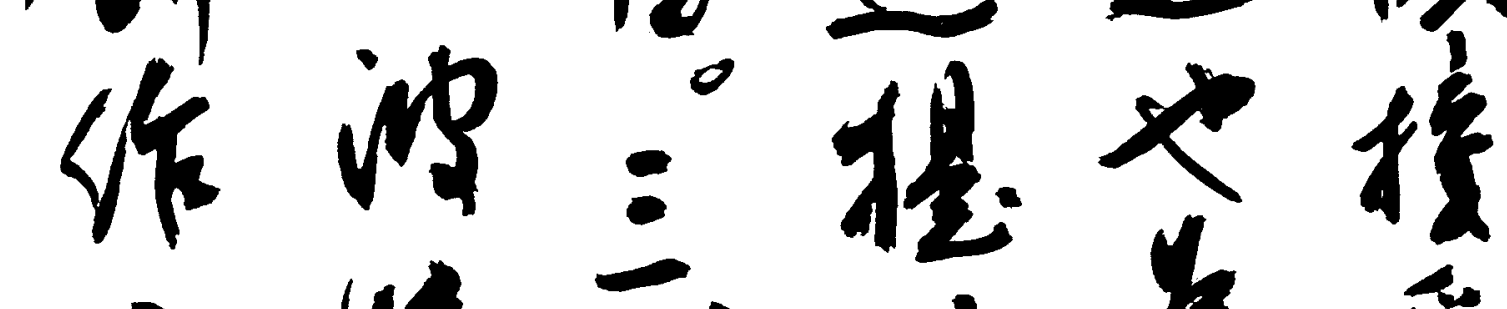

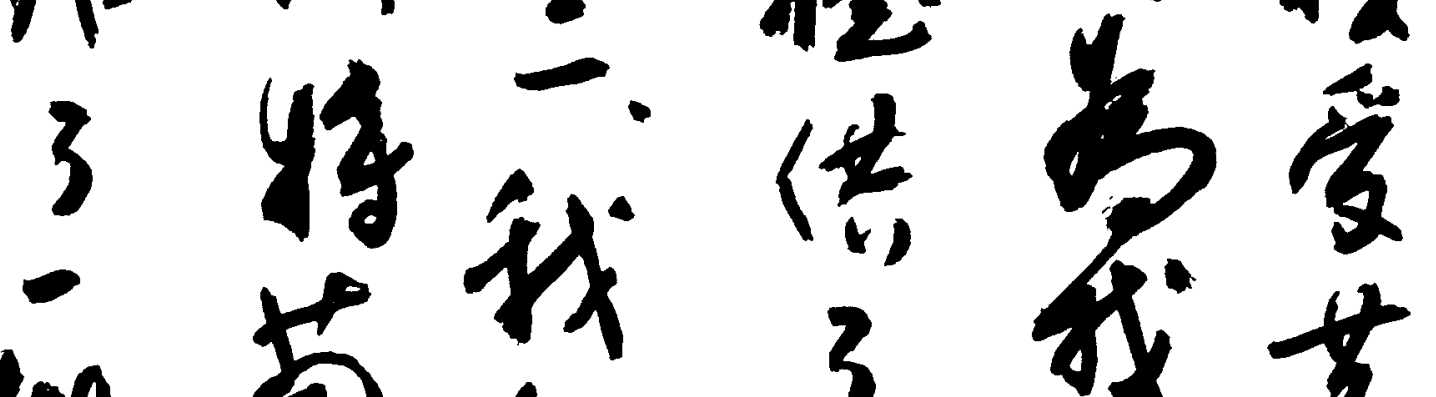
和菊的当我菜 新管富后者

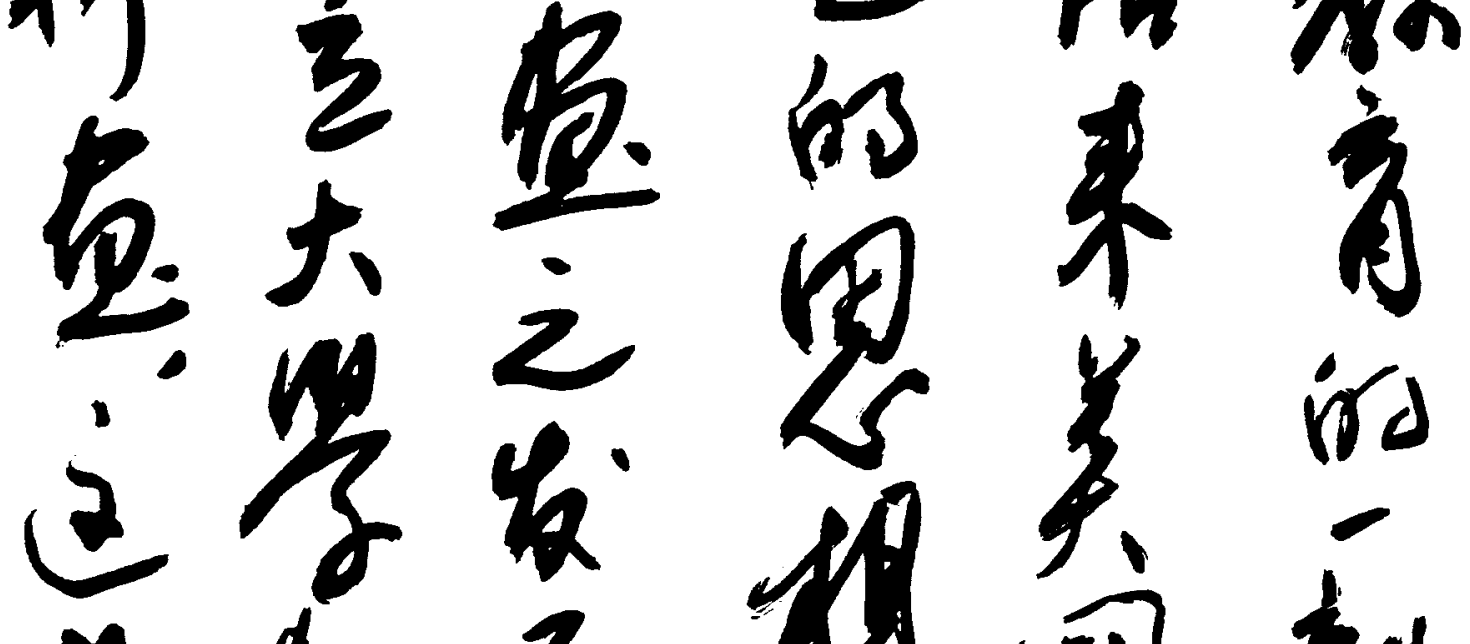

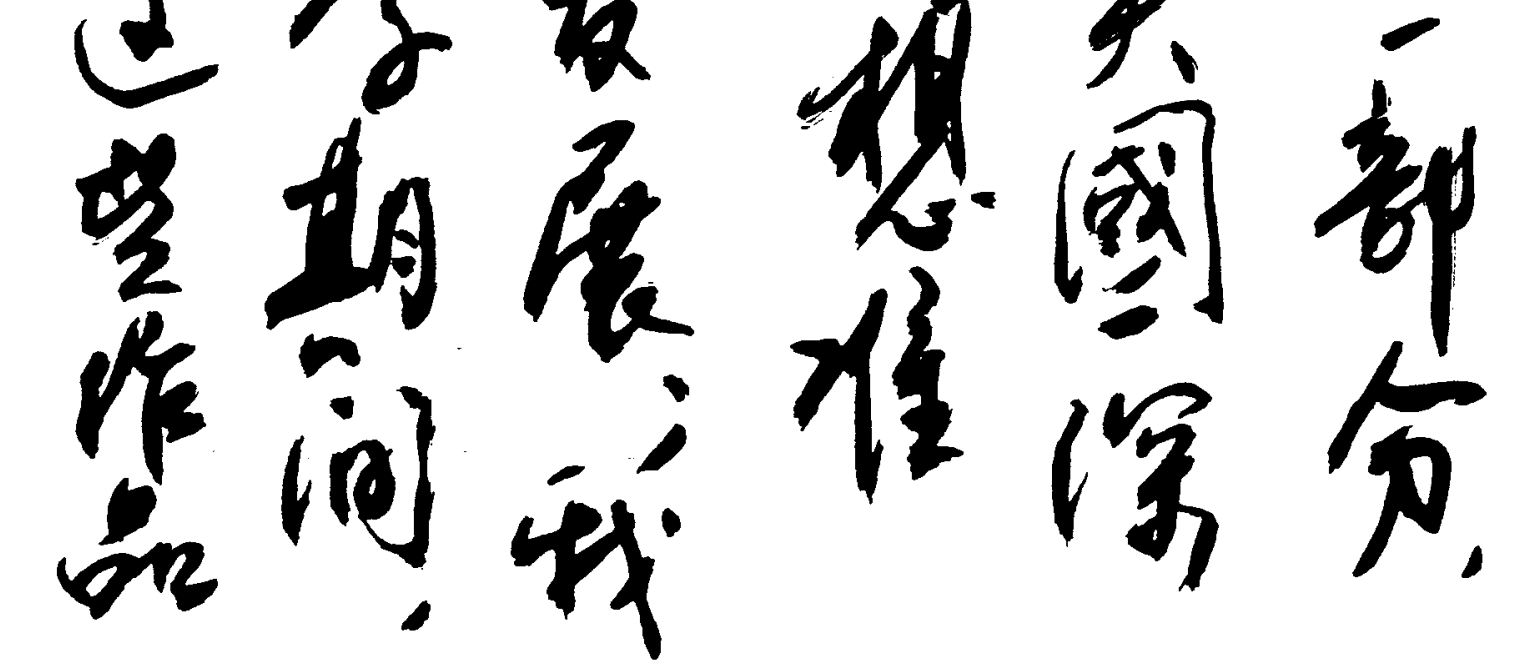


完的色式用筑 慗售数来地站 家要要制象调

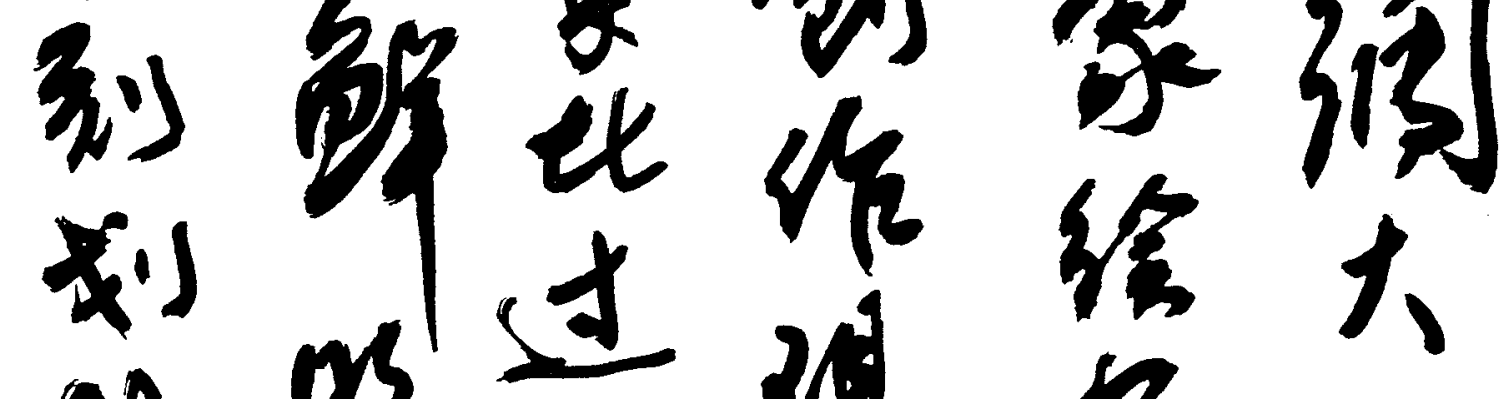
些吃过现宣的 较物至实中线 深思中言的 我造国等构色。

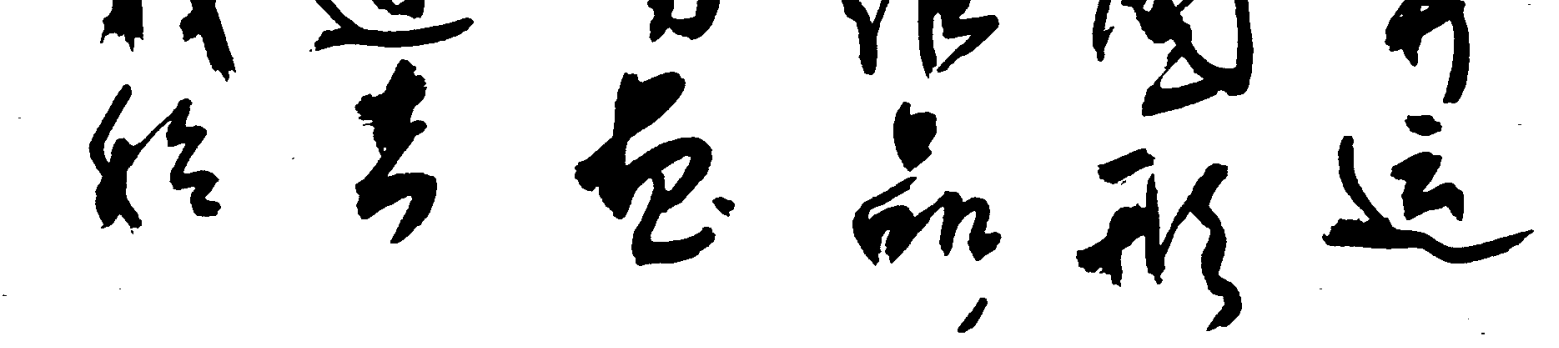




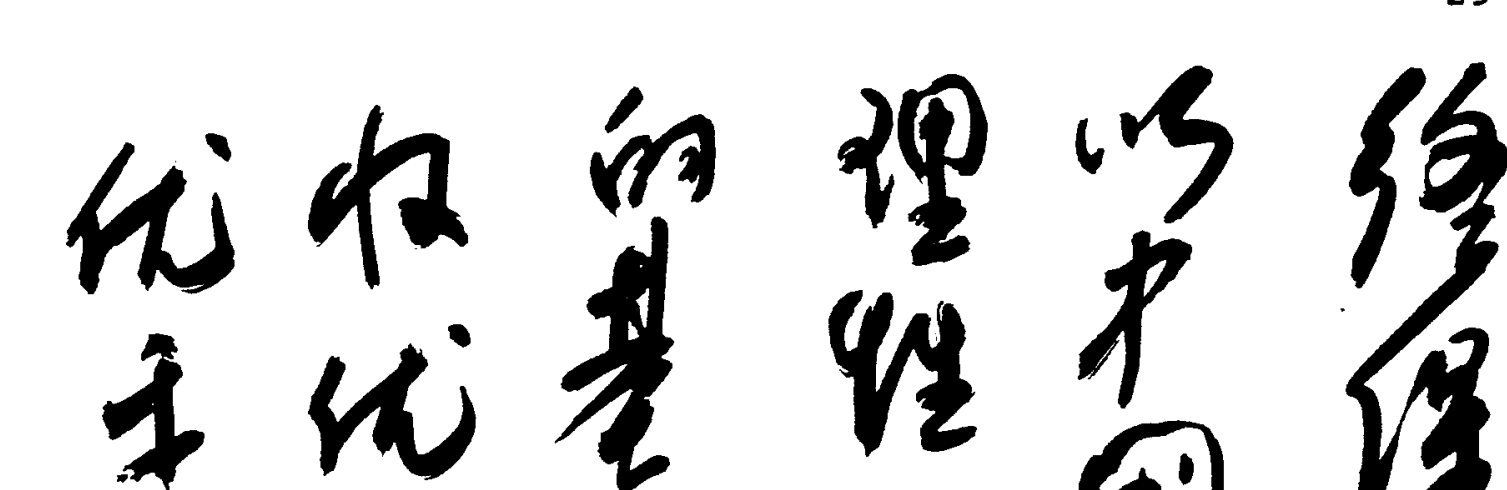

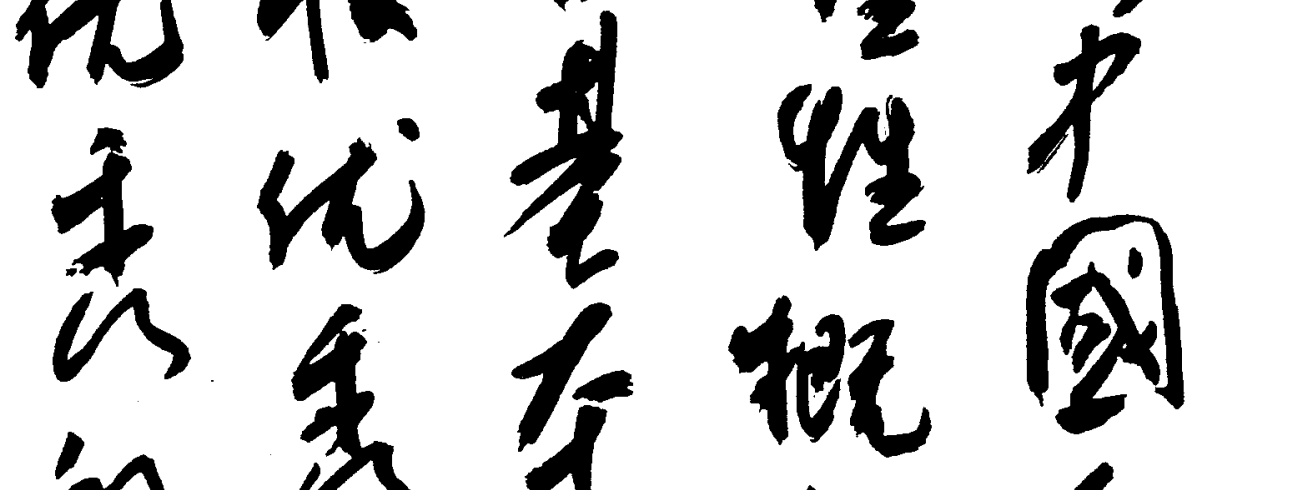
的爱年概国标

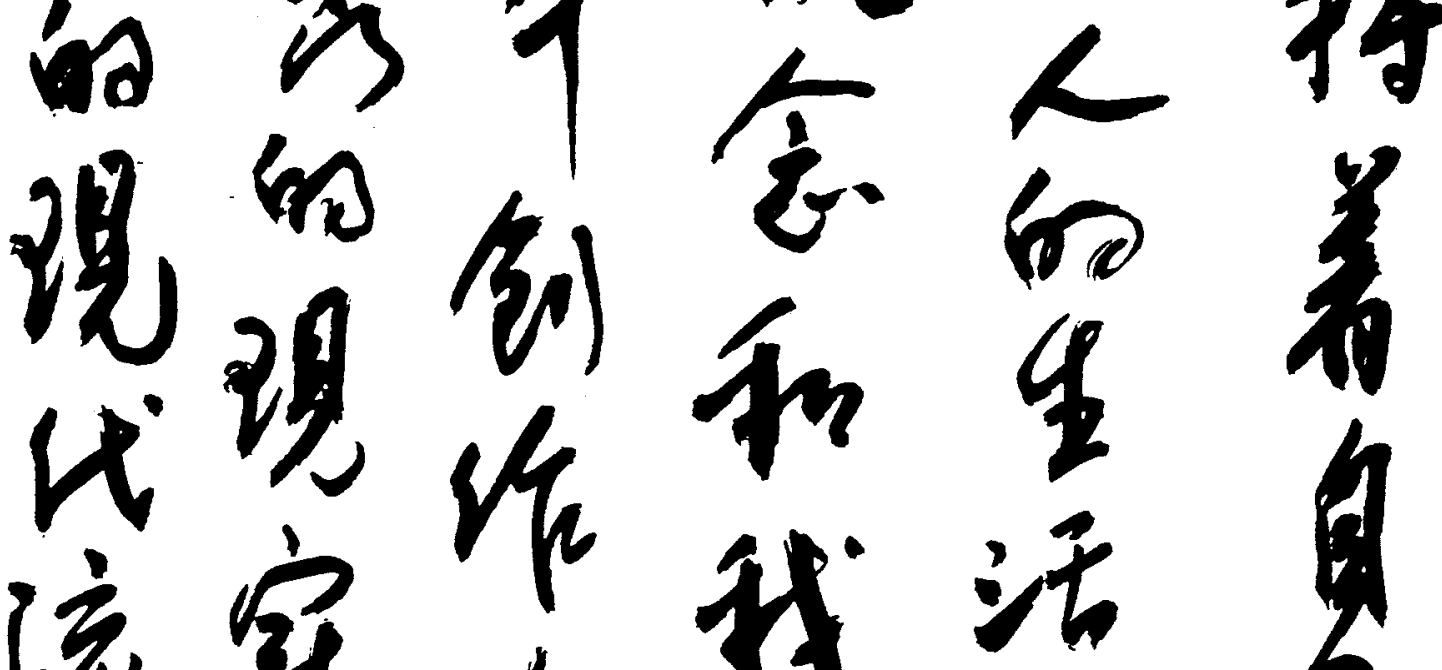
流宗西势活易

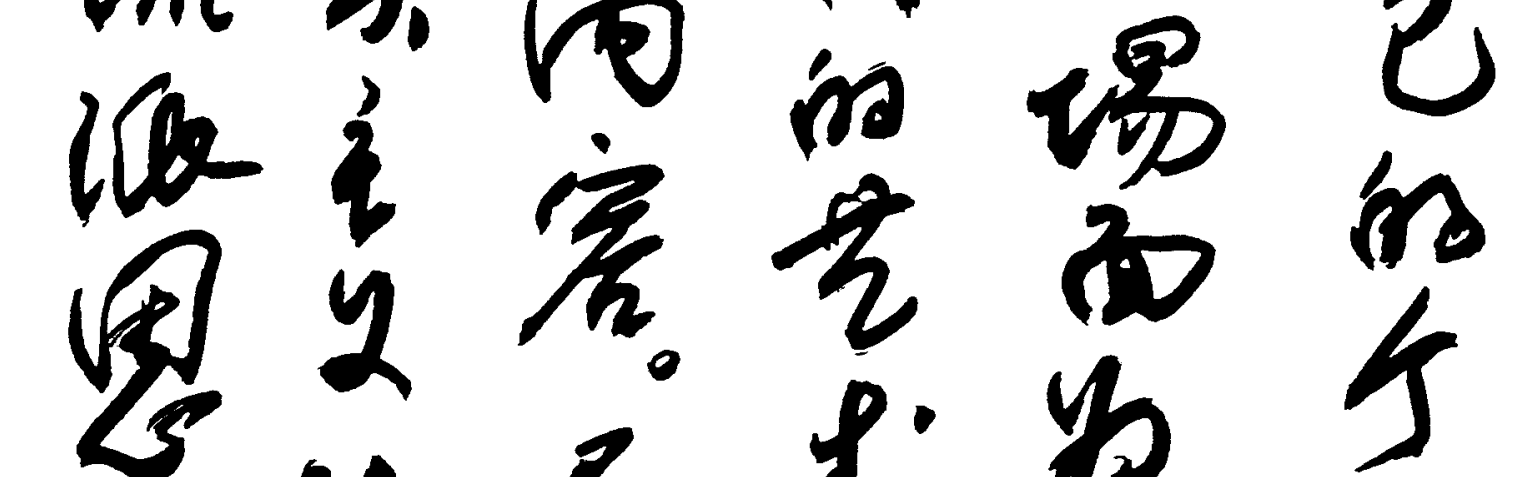
维技含起等

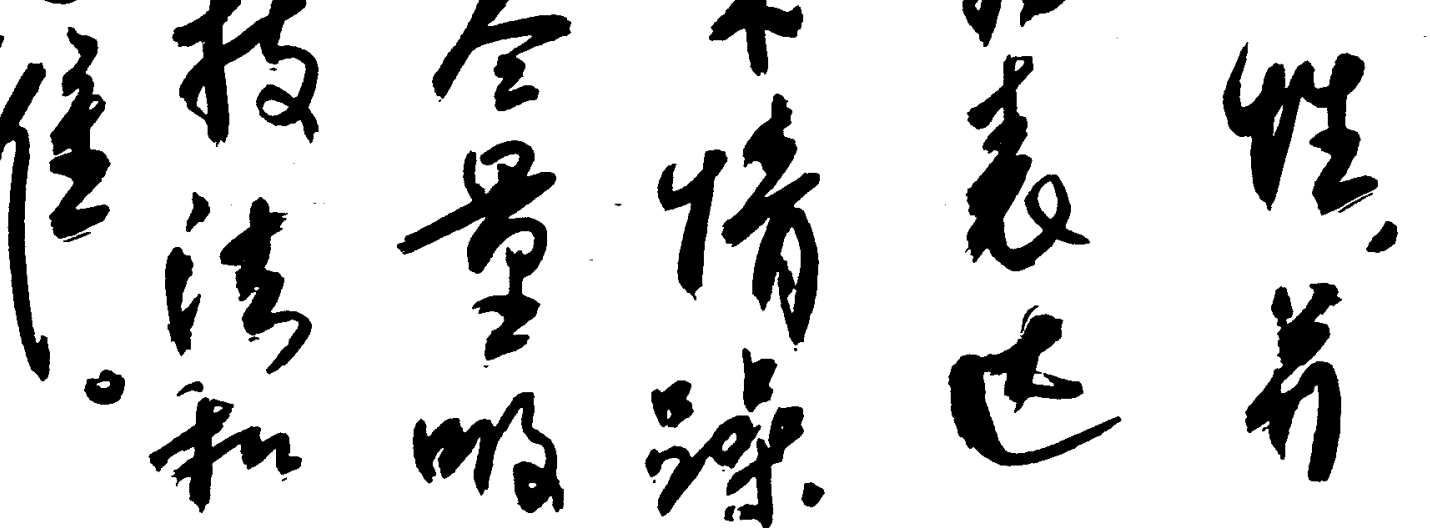




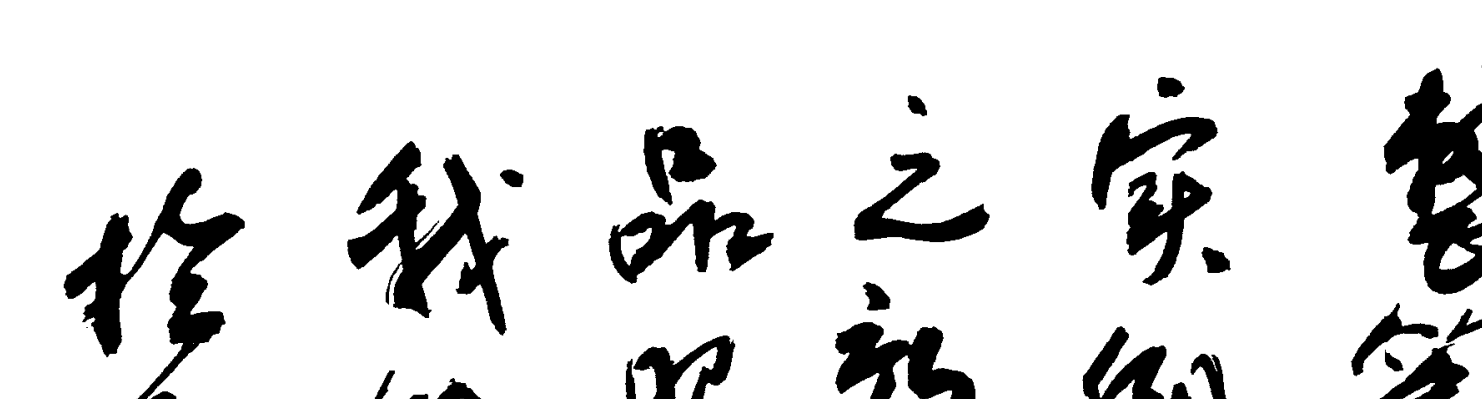
元的照效例简 竞左。果。海 年详文蒸冬 稿细后分例

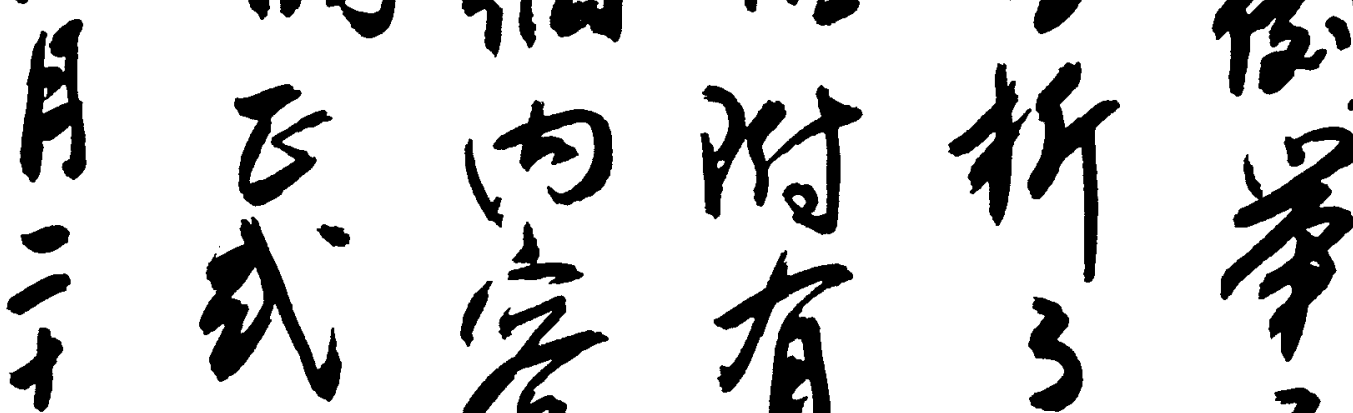
武客有3

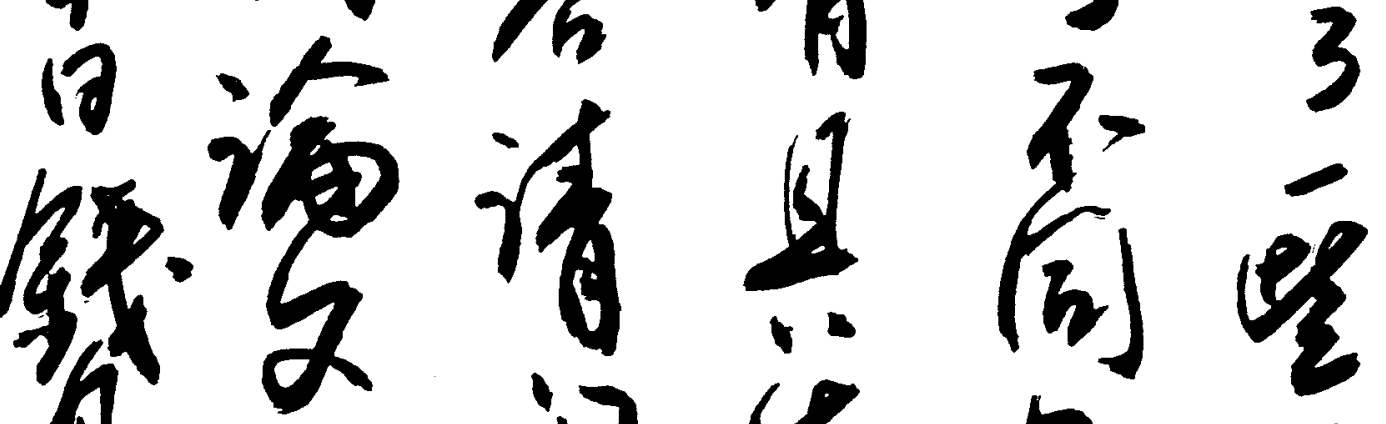

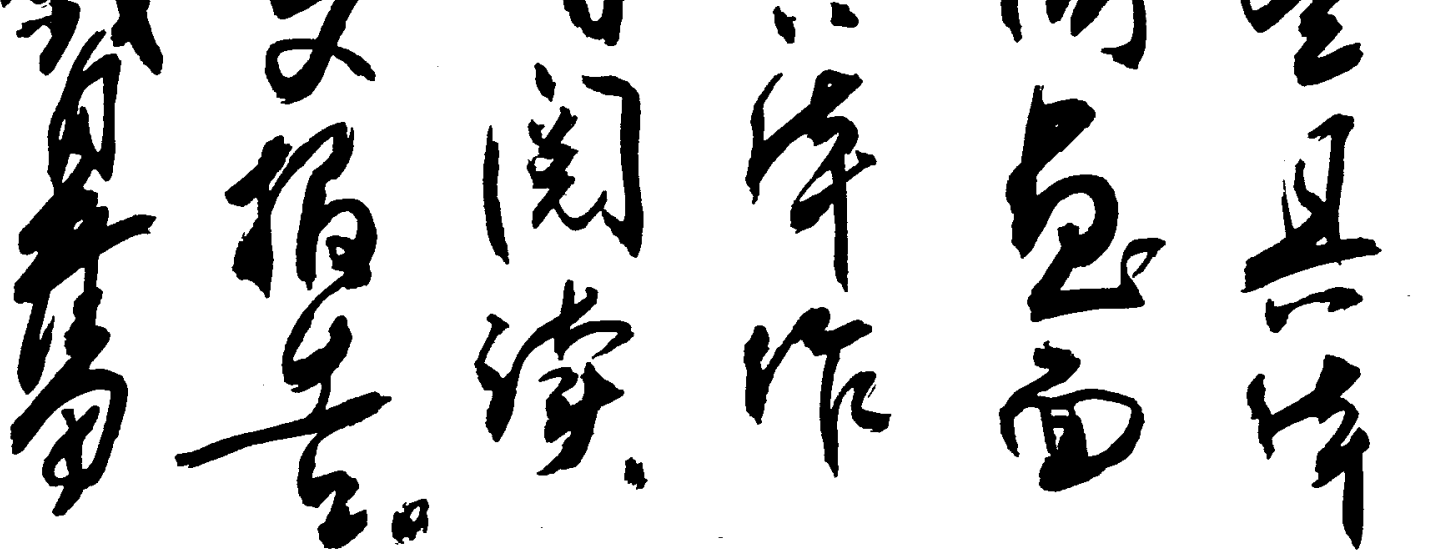

